\title{
The preventive effect of dexmedetomidine on adverse reactions induced by uterotonics in cesarean section: a meta-analysis
}

\section{Lingxi Kong(Former Corresponding Author)}

Chongqing Medical University First Affiliated Hospital

\section{Xuefeng Shan}

First Affiliated Hospital of Chongqing Medical University

\section{Hongmei Wang}

Chongqing Medical University First Affiliated Hospital

\section{Yingying Ren}

Chongqing Medical University First Affiliated Hospital

\section{Yang Yang}

Chongqing Medical University First Affiliated Hospital

Feng Qiu(New Corresponding Author) ( $\sim$ 3283682632@qq.com )

Research article

Keywords: Dexmedetomidine, Cesarean section, Uterotonics, Meta-analysis

Posted Date: October 29th, 2019

DOI: https://doi.org/10.21203/rs.2.16542/v1

License: (a) (i) This work is licensed under a Creative Commons Attribution 4.0 International License. Read Full License 


\section{Abstract}

Background: To evaluate the preventive effect of dexmedetomidine(DEX) on adverse reactions induced by uterotonics used in cesarean section.

Methods: Randomized controlled trials(RCTs) comparing dexmedetomidine with placebo on preventing the side effects of uterotonics in cesarean section were searched in PubMed, The Cochrane Library, and CNKI.

Results: Fifteen articles with 1174 patients were included in this study. Compared with placebo, DEX significantly reduced the incidence of adverse drug reactions, such as nausea, vomiting, facial flushing, chest distress, hypertension and tachycardia ([OR $=0.12,95 \% \mathrm{Cl}(0.09,0.17), \mathrm{P}<0.00001]$, [OR $=0.12,95 \% \mathrm{Cl}(0.09$, $0.18), \mathrm{P}<0.00001],[\mathrm{OR}=0.21,95 \% \mathrm{Cl}(0.16,0.29), \mathrm{P}<0.00001],[\mathrm{OR}=0.19,95 \% \mathrm{Cl}(0.12,0.30), \mathrm{P}<0.00001]$, [OR=0.09, 95\% Cl $(0.05,0.14), \mathrm{P}<0.00001]$, [OR=0.04, 95\% Cl $(0.02,0.07), \mathrm{P}<0.00001])$, which were induced by uterotonics used in cesarean section.

Conclusion: Dexmedetomidine can prevent adverse reactions including nausea, vomiting, facial flushing, chest distress, hypertension and tachycardia caused by uterotonics used in cesarean section.

\section{Background}

Postpartum hemorrhage is a serious complication of pregnant women and also the leading cause of maternal death worldwide. The four major causes of postpartum hemorrhage are uterine fatigue, birth canal damage, placental factors and coagulation dysfunction, of which uterine fatigue is the most common one, accounting for $70 \% \sim 90 \%{ }^{[1]}$. And hemorrhage caused by uterine fatigue is much more common in caesarean section than natural delivery. WHO guidelines on prevention and treatment of postpartum hemorrhage also clearly points out that all of the parturients should use uterotonics prophylaciously in the third stage of labor, which can prevent and reduce the occurrence of postpartum hemorrhage ${ }^{[2]}$.At present, the commonly used uterotonics in clinical practice include oxytocin, carboprost tromethamine and carbetocin, etc. However, these agents have a series of adverse reactions, including gastrointestinal discomfort(nausea and vomiting) and cardiovascular side effects(increased blood pressure, increased heart rate, chest tightness, facial flushing) ${ }^{[3]}$. These adverse reactions usually have a bad impact on surgical operation, anesthesia safety and postpartum recovery. Dexmedetomidine(DEX), a new type of highly selective alpha-2 adrenergic agonist with sedative, analgesic and anti-anxiety effects, has been widely used in cesarean section these days. Studied has been reported that it can reduce the incidence of nausea, vomiting and chilla during spinal anesthesia in cesarean

section $^{[4,5,6,7]}$. And in recent years, there is a increasing number of randomized controlled trials(RCTs) involving the use of DEX in cesarean section with the use of uterotonic agents. So the aim of this study is to explore and evaluate the effect of dexmedetomidine in the prevention of side effects of uterotonic in cesarean section through meta-analysis and to provide evidence-based basis for the rational use of drugs for obstetric surgery.

\section{Materials And Methods}


This meta-analysis was written according to the preferred reporting items for systematic reviews and PRISMA statement and a drafted study protocol was also made which was consistent with the Cochrane Collaboration format.

Inclusion criteria

(1)Study design:only randomized controlled trials (RCTs) were considered in this study.

(2)Participants: pregnancy patients undergoing scheduled cesarean section, with American Society of Anesthesiologists (ASA) physical status I-II.

(3)Intervention: placebo(saline) was used in the control group and dexmedetomidine was used in the observation group.

(4)Outcomes: evaluation indicators of adverse reactions included the following: nausea, vomiting, facial flushing, chest distress, hypertension and tachycardia.

Exclusion criteria

(1) non-RCTs;

(2) Reviews;

(3) Animal experimental research and in vitro experimental research

(4) Unclear methods of drug administration;

(5) No intervention of uterotonics in cesarean section;

(6) Dexmedetomidine used in combination with other drugs in treatment;

(7)No data provided for the calculating of adverse reactions.

(8) Republished literatures.

Search strategy

Pubmed, Cochrane Library,Embase,CNKI and other Chinese databases were searched to indentify the clinical trials related to dexmedetomidine used in cesarean section. The retrieval period was from the establishment of each database to June 2019 and the search terms are "Dexmedetomidine" and "Cesarean". Titles, abstracts, and full texts of relevant articles were screened after the excluding of duplicated ones.

Study selection and data extraction

Two independent researchers screened the literatures strictly according to the inclusion and exclusion criteria and extracted relevant information and data from the included literatures independently. The information 
mainly included basic information, research objective, interventions and outcome indicators. The two researchers cross-checked and discussed it after completion.

Accessing of Literature quality

Literature quality was accessed by two researchers separately according to Jadad scale. The evaluated items included the following four: (1) whether it was randomized and whether the method was described and correct; (2) whether blinding was performed and whether the method was correct(3) whether allocation concealment was implied and whether the method was correct;(4) whether the data were complete. Literature with a score bellow 4 was considered of low quality.

Statistical methods

Data analysis was performed using RevMan5.3 statistical software provided by Cochrane Library(The Cochrane Collaboration, The Nordic Cochrane Center, Copenhagen, Denmark). In our study, incidence of side effects belongs to categorical outcomes, so the odds risks (ORs) and $95 \%$ Confidence Interval(Cl) were calculated. Heterogeneity test or Q-test was adopted for heterogeneity analysis. If $\mathrm{I}^{2}<50 \%$, the data was not significantly homogeneous, fixed effect model was used; otherwise, random effect model was selected. The results of meta-analysis described in forest maps.

\section{Results}

Results of literature searching

A total of 1093 articles were initially identified and 611 literatures were retained after excluding duplicate ones. 127 articles remained through screening of titles and abstracts. Reviews, non-clinical trial studies and those that did not meet the objective of our study were discarded. The 127 studies were screened in full text according to the inclusion and exclusion criteria. 100 articles was excluded in which the participants were not in conformity with the requirements, the uterotonic agents was not applied, saline was not used for control group or the use of DEX was in combination with other drugs. After the ruling out of studies in which the outcome index was unmatched or the data was incomplete, finally a total of fifteen articles remained. The flow chart of study selection process is shown in figure 1.

Figure1. Flow diagram of the study selection process

The basic information of the fifteen studies is shown in table 1. A total of 1174 patients were included, including 589 cases in the observation group (DEX) and 585 cases in the control group (saline).All the subjects were given uterotonic agents (oxytocin, caprostatin trimethamine, or carbetocin) after delivery. Patients in the observation group were given dexmedetomidine by injection and those in control group were given the same amount of saline.. Other control adjuvants included ondansetron $\left.{ }^{[8,9}\right]$, propofol $^{[10,11]}$, droperido ${ }^{[12]}$, mifenafluoride mixture ${ }^{[13]}$, midazolam ${ }^{[14]}$. Dosages of DEX for the fifteen RCTs were quite not the same. For most of the RCTs, DEX is given with a dose of $1.0 \mathrm{ug} \cdot \mathrm{kg}^{-1}$ with or without a maintenance dose of $0.4 \mathrm{ug} \cdot \mathrm{kg}^{-1} \cdot \mathrm{h}^{-1}$, while three of the studies involving different dosage groups of DEX ${ }^{[15,16,17]}$. Different kinds of uterotonics was administrated, oxytocin(20U or 30U) with or without 
carboprost tromethamine (250ug) were used in ten of the RCTs $\left.{ }^{[8,9,11,14,17-22}\right]$, carboprost tromethamine in four ${ }^{[10,13,15,16]}$, and cabernet oxytocin(100ug) in one ${ }^{[12]}$. Anaesthesia method of all the studies fell into two categories,epidural anesthesia spinal-epidural anesthesia.

Quality evaluation of the articles

The included fifteen articles were all RCTs, in which four trials didn't explain the concrete randomized method $[8,9,21,22]$, one paper adopted the method of draw ${ }^{[15]}$, one piece applied computer random sequence ${ }^{[17]}$, the remained took random number table method ${ }^{[10-14,16,18-20]}$. Blind method was mentioned in two of the research $^{[14,17]}$. And the detail information of allocation concealment, cases of exit and lost to follow-up were reported in none of the fifteen trails. The quality scores of the included literatures were shown in table 2 . As we can draw from it, two of the trials were graded 4 scores, nine 3 scores and four 2 scores, and only two of them were of high quality.

Table 1. Basic data of included studies 


\begin{tabular}{|c|c|c|c|c|c|c|c|c|c|c|}
\hline Iuthors & Group & $\begin{array}{c}\text { Sample } \\
\text { size }\end{array}$ & Age(year) V & Weight(Kg) & $\begin{array}{c}\text { Gestational } \\
\text { week }\end{array}$ & Intervention & $\begin{array}{c}\text { Target } \\
\text { outcomes }\end{array}$ & $\begin{array}{c}\text { Administration } \\
\text { of uterotonics }\end{array}$ & Anaesthesia method & Basic anaesthetics \\
\hline \multirow[t]{3}{*}{ ən $2015^{[8]}$} & DEX & 30 & $27.0 \pm 3.7$ & $65.9 \pm 5.1$ & & $\begin{array}{c}\text { loading dose is } 1.0 \mathrm{ug} \cdot \mathrm{kg}^{-} \\
{ }^{1} \text {, maintenance dose is } \\
0.4 \mathrm{ug} \cdot \mathrm{kg}^{-1} \cdot \mathrm{h}^{-1}\end{array}$ & $1,2,3,4,5,6$ & $\begin{array}{l}\text { oxytocin } 20 \mathrm{U} \square \\
\text { carboprost } \\
\text { tromethamine }\end{array}$ & $\begin{array}{l}\text { spinal - epidural } \\
\text { anesthesia }\end{array}$ & $\begin{array}{c}0.5 \% \text { bupivacaine } \\
1.5 \mathrm{ml}\end{array}$ \\
\hline & Ondansetron & 30 & $26.9 \pm 3.5$ & $65.6 \pm 7.1$ & & $\begin{array}{l}4 \mathrm{mg} \text { in intravenous } \\
\text { injection }\end{array}$ & & $250 u g$ & & \\
\hline & saline & 30 & $27.2 \pm 2.7$ & $66.2 \pm 5.9$ & & equal volume & & & & \\
\hline \multirow[t]{3}{*}{ २2015 } & DEX & 30 & $28.1 \pm 3.6$ & $66.3 \pm 5.8$ & & $\begin{array}{c}\text { loading dose is } 1.0 \mathrm{ug} \cdot \mathrm{kg}^{-} \\
{ }^{1} \text {, maintenance dose is } \\
0.4 \mathrm{ug} \cdot \mathrm{kg}^{-1} \cdot \mathrm{h}^{-1}\end{array}$ & $1,2,3,4$ & $\begin{array}{l}\text { oxytocin } 20 \mathrm{U} \square \\
\text { carboprost } \\
\text { tromethamine }\end{array}$ & epidural anesthesia & $\begin{array}{l}2 \% \text { lidocaine } 3 \mathrm{ml} \square \\
0.75 \text { ropivacaine } 10- \\
15 \mathrm{ml}\end{array}$ \\
\hline & Ondansetron & 30 & $27.9 \pm 3.4$ & $69.5 \pm 6.2$ & & $\begin{array}{l}4 \mathrm{mg} \text { in intravenous } \\
\text { injection }\end{array}$ & & $250 u g$ & & \\
\hline & saline & 30 & $28.3 \pm 3.3$ & $64.7 \pm 4.9$ & & equal volume & & & & \\
\hline \multirow[t]{2}{*}{$2014^{[10]}$} & DEX & 31 & $28.0 \pm 2.9$ & $66.2 \pm 6.1$ & $38.6 \pm 0.9$ & $\begin{array}{c}\text { loading dose is } 1.0 \mathrm{ug} \cdot \mathrm{kg}^{-} \\
{ }^{1} \text {, maintenance dose is } \\
0.4 \mathrm{ug} \cdot \mathrm{kg}^{-1} \cdot \mathrm{h}^{-1}\end{array}$ & $1,2,3,4$ & $\begin{array}{c}\text { carboprost } \\
\text { tromethamine }\end{array}$ & epidural anesthesia & $\begin{array}{c}2 \% \text { lidocaine } 2 \mathrm{ml} \\
0.75 \text { ropivacaine } \\
15 \mathrm{ml}\end{array}$ \\
\hline & propofol & 31 & $27.5 \pm 3.5$ & $68.2 \pm 6.3$ & $38.2 \pm 0.9$ & $\begin{array}{l}\text { loading dose is } 1 \mathrm{mg} \cdot \mathrm{kg} \text { - } \\
1, \mathrm{maintenance} \text { dose is } \\
3 \mathrm{mg} \cdot \mathrm{kg}^{-1} \cdot \mathrm{h}^{-1} \\
\text { equal volume }\end{array}$ & & & & \\
\hline \multirow[t]{3}{*}{$12015^{[11]}$} & DEX & $40 \quad 2$ & $27.56 \pm 3.476$ & $67.68 \pm 4.33$ & $39.65 \pm 1.54$ & $1.0 \mathrm{ug} \cdot \mathrm{kg}^{-1}, 0.4 \mathrm{ug} \cdot \mathrm{kg}^{-1} \cdot \mathrm{h}^{-1}$ & $1,2,3,4,5,6$ & oxytocin $20 \mathrm{U} \square$ & epidural anesthesia & $1 \%$ lidocaine $2 \mathrm{ml} \square$ \\
\hline & propofol & $40 \quad 2$ & $27.83 \pm 4.526$ & $67.14 \pm 4.673$ & $39.23 \pm 1.54$ & $1 \mathrm{mg} \cdot \mathrm{kg}^{-1}, 3 \mathrm{mg} \cdot \mathrm{kg}^{-1} \cdot \mathrm{h}^{-1}$ & & $\begin{array}{l}\text { carboprost } \\
\text { tromethamine }\end{array}$ & & $\begin{array}{c}0.75 \text { ropivacaine } \\
15 \mathrm{ml}\end{array}$ \\
\hline & saline & $40 \quad 2$ & $27.39 \pm 3.726$ & $66.94 \pm 4.73$ & $39.54 \pm 1.62$ & equal volume & & $250 u g$ & & \\
\hline \multirow[t]{4}{*}{$\ln 2018^{[12]} \mathrm{I}$} & DEX+droperidol & 30 & $27.1 \pm 2.5$ & $72.5 \pm 6.5$ & $39.3 \pm 1.1$ & $\begin{array}{c}0.2 \mathrm{ug} \cdot \mathrm{kg}^{-1} \text { of DEX with } 1.25 \\
\mathrm{mg} \text { of droperidol }\end{array}$ & $1,2,3,4,5,6$ & $\begin{array}{c}100 u g \\
\text { cabernet }\end{array}$ & $\begin{array}{l}\text { spinal - epidural } \\
\text { anesthesia }\end{array}$ & bupivacaine $7.5^{-1} 0 \mathrm{ml}$ \\
\hline & DEX & 30 & $26.5 \pm 3.3$ & $69.9 \pm 8.0$ & $39.1 \pm 1.1$ & $0.2 \mathrm{ug} \cdot \mathrm{kg}^{-1}$ & & oxytocin & & \\
\hline & droperidol & 30 & $27.1 \pm 3.0$ & $72.5 \pm 8.2$ & $39.1 \pm 1.2$ & $1.25 \mathrm{mg}$ & & & & \\
\hline & saline & 30 & $26.0 \pm 3.1$ & $71.4 \pm 8.2$ & $38.8 \pm 1.4$ & equal volume & & & & \\
\hline \multirow[t]{3}{*}{$\lg 2017^{[13]}$} & DEX & 40 & $26.3 \pm 2.8$ & $66.3 \pm 4.0$ & & $1 \mathrm{ug} \cdot \mathrm{kg}^{-1}$ & $3,4,5,6$ & carboprost & spinal - epidural & bupivacaine $9 \mathrm{mg} \square$ \\
\hline & $\begin{array}{l}\text { Mifenafluoride } \\
\text { mixture }\end{array}$ & 40 & $26.5 \pm 2.2$ & $66.8 \pm 3.5$ & & $\begin{array}{c}\text { midazolam } 2 \mathrm{mg}+\text { fentanyl } \\
0.025 \mathrm{mg}+\text { droperidol } 1.25 \mathrm{mg}\end{array}$ & & $\begin{array}{l}\text { tromethamine } \\
250 \text { ug }\end{array}$ & anesthesia & $\begin{array}{l}0.5 \% \text { ropivacaine } 5^{-} \\
{ }^{1} 0 \mathrm{ml}\end{array}$ \\
\hline & saline & 40 & $26.1 \pm 3.0$ & $67.3 \pm 2.8$ & & equal volume & & & & \\
\hline \multirow[t]{4}{*}{$12016^{[14]}$} & $\mathrm{DEX}$ & 33 & $22-32$ & $50-84$ & & $\begin{array}{c}\text { loading dose is } 0.1 \mathrm{ug} \cdot \mathrm{kg}^{-} \\
{ }^{1} \text {, maintenance dose is } \\
0.4 \mathrm{ug} \cdot \mathrm{kg}^{-1} \cdot \mathrm{h}^{-1}\end{array}$ & $1,2,3,4,5,6$ & $\begin{array}{l}\text { oxytocin } 20 \mathrm{U} \square \\
\text { carboprost } \\
\text { tromethamine }\end{array}$ & $\begin{array}{l}\text { spinal - epidural } \\
\text { anesthesia }\end{array}$ & \\
\hline & midazolam & 33 & & & & loading dose is & & $250 u g$ & & \\
\hline & & & & & & $\begin{array}{c}1 \mathrm{mg}, \mathrm{maintenance} \text { dose } \\
\text { is } 1 \mathrm{mg} \cdot \mathrm{h}^{-1}\end{array}$ & & & & \\
\hline & saline & 29 & & & & equal volume & & & & \\
\hline \multirow[t]{3}{*}{$2016^{[15]}$} & DEX & 603 & $30.69 \pm 4.15$ & & $38.92 \pm 1.39$ & $\begin{array}{c}\text { loading dose is } 1.0 \mathrm{ug} \cdot \mathrm{kg}^{-} \\
1 \text {, maintenance dose is } \\
0.6 \mathrm{ug} \cdot \mathrm{kg}^{-1} \cdot \mathrm{h}^{-1}\end{array}$ & $1,2,3,4$ & $\begin{array}{c}\text { carboprost } \\
\text { tromethamine }\end{array}$ & epidural anesthesia 2 & $\begin{array}{l}2 \% \text { lidocaine } 3 \mathrm{ml} \square 1 \% \\
\text { ropivacaine } 8 \mathrm{ml}\end{array}$ \\
\hline & DEX & 603 & $30.72 \pm 4.16$ & & $38.93 \pm 1.42$ & $\begin{array}{c}\text { loading dose is } 1.0 \mathrm{ug} \cdot \mathrm{kg}^{-} \\
{ }^{1} \text {, maintenance dose is } \\
0.3 \mathrm{ug} \cdot \mathrm{kg}^{-1} \cdot \mathrm{h}^{-1}\end{array}$ & & & & \\
\hline & saline & 603 & $30.55 \pm 4.21$ & & $37.99 \pm 1.42$ & equal volume & & & & \\
\hline \multirow[t]{3}{*}{$\lg 2015^{[16]}$} & DEX & 30 & $30.7 \pm 4.2$ & $66.3 \pm 7.4$ & $38.9 \pm 1.4$ & $\begin{array}{c}\text { loading dose is } 1.0 \mathrm{ug} \cdot \mathrm{kg}^{-} \\
{ }^{1} \text {, maintenance dose is } \\
0.6 \mathrm{ug} \cdot \mathrm{kg}^{-1} \cdot \mathrm{h}^{-1}\end{array}$ & $1,2,3,4$ & $\begin{array}{c}\text { carboprost } \\
\text { tromethamine }\end{array}$ & epidural anesthesia 2 & $\begin{array}{l}2 \% \text { lidocaine } 3 \mathrm{ml} \square 1 \% \\
\text { ropivacaine } 8 \mathrm{ml}\end{array}$ \\
\hline & DEX & 30 & $30.8 \pm 3.6$ & $68.5 \pm 6.8$ & $38.1 \pm 0.8$ & $\begin{array}{c}\text { loading dose is } 1.0 \mathrm{ug} \cdot \mathrm{kg}^{-} \\
{ }^{1} \text {, maintenance dose is } \\
0.3 \mathrm{ug} \cdot \mathrm{kg}^{-1} \cdot \mathrm{h}^{-1}\end{array}$ & & & & \\
\hline & saline & 30 & $30.8 \pm 4.9$ & $70.7 \pm 5.3$ & $38.5 \pm 1.5$ & equal volume & & & & \\
\hline \multirow[t]{3}{*}{$12015^{[17]}$} & DEX & 40 & $29 \pm 3$ & $72 \pm 7$ & $38.7 \pm 1.2$ & $1 \mathrm{ug} \cdot \mathrm{kg}^{-1}$ & $1,2,3,4,5$ & oxytocin $20 \mathrm{U} \square$ & spinal - epidural & $0.5 \%$ bupivacaine \\
\hline & DEX & 40 & $30 \pm 6$ & $73 \pm 8$ & $38.6 \pm 0.9$ & $0.5 \mathrm{ug} \cdot \mathrm{kg}^{-1}$ & & $\begin{array}{l}\text { carboprost } \\
\text { tromethamine }\end{array}$ & anesthesia & $\begin{array}{c}1.5 \mathrm{ml} 1 \% \text { lidocaine } \\
5 \mathrm{ml}\end{array}$ \\
\hline & saline & 40 & $31 \pm 5$ & $75 \pm 6$ & $39.1 \pm 0.7$ & $20 \mathrm{ml}$ & & $250 u g$ & & \\
\hline $2014^{[18]}$ & DEX & 20 & $28.2 \pm 2.3$ & $67 \pm 5$ & $39.7 \pm 1.1$ & $\begin{array}{l}\text { loading dose is } 0.1 \mathrm{ug} \cdot \mathrm{kg}^{-} \\
{ }^{1} \text {, maintenance dose is } \\
0.4 \mathrm{ug} \cdot \mathrm{kg}^{-1} \cdot \mathrm{h}^{-1} \\
\text { Page } 6 / 15\end{array}$ & $1,2,3,4,5,6$ & $\begin{array}{l}\text { oxytocin } 20 \mathrm{U} \square \\
\text { carboprost }\end{array}$ & epidural anesthesia & $\begin{array}{c}1 \% \text { lidocaine } 3 \mathrm{ml} \\
0.75 \text { ropivacaine } \\
10 \mathrm{ml}^{-1} 5 \mathrm{ml}\end{array}$ \\
\hline
\end{tabular}




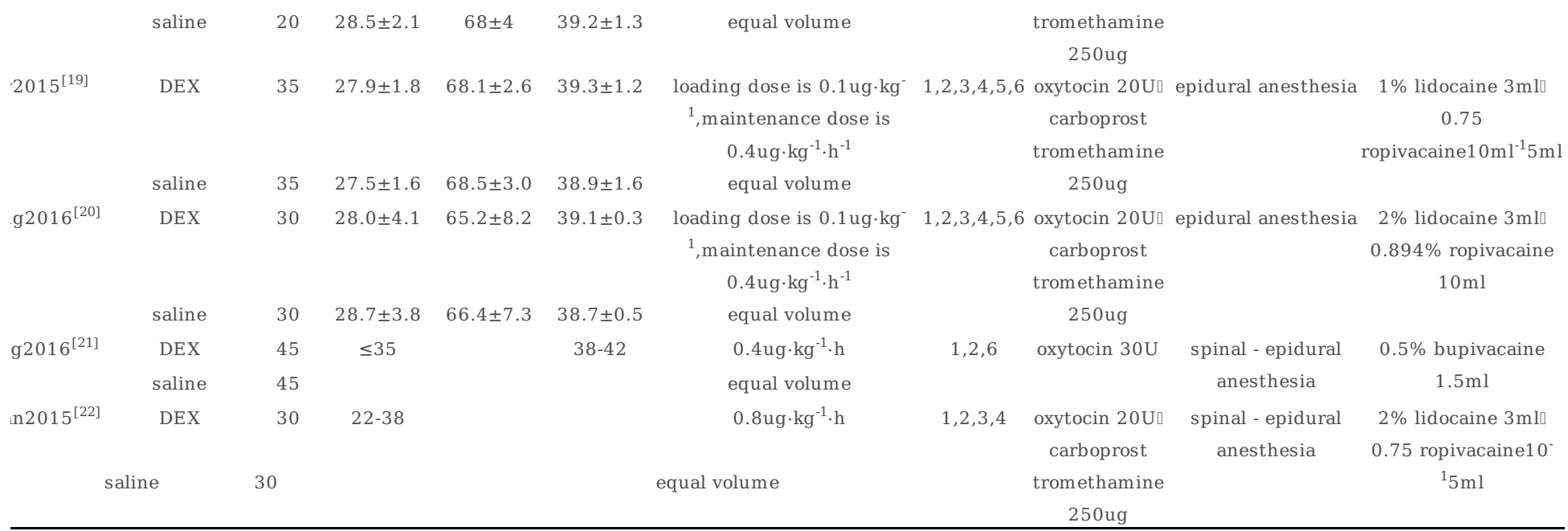

Note: 1:nausea, 2:vomiting,3:facial flushing,4:chest distress, 5:hypertetion,6: tachycardia

Table 2. Jadad scores of include studies

\begin{tabular}{lcccccc}
\hline Authors & Country & Jadad scores & Randomised & Blinding & Concealment allocation & Follow-up \\
\hline Chen2015 & China & 2 & 1 & 0 & 1 & 0 \\
LiQ2015 & China & 2 & 1 & 0 & 1 & 0 \\
Sun2014 & China & 3 & 2 & 0 & 1 & 0 \\
LiH2015 & China & 3 & 2 & 0 & 1 & 0 \\
Duan2018 & China & 3 & 2 & 0 & 1 & 0 \\
Liang2017 & China & 3 & 2 & 0 & 1 & 0 \\
Wu2016 & China & 4 & 2 & 1 & 1 & 0 \\
Li2016 & China & 3 & 2 & 0 & 1 & 0 \\
Wang2015 & China & 3 & 2 & 0 & 1 & 0 \\
Liu2015 & China & 4 & 2 & 1 & 1 & 0 \\
Ni2014 & China & 3 & 2 & 0 & 1 & 0 \\
Lv2015 & China & 3 & 2 & 0 & 1 & 0 \\
Yang2016 & China & 3 & 2 & 0 & 1 & 0 \\
Xing2016 & China & 2 & 1 & 0 & 1 & 0 \\
Yuan2015 & China & 2 & 1 & 0 & 1 & 0 \\
\hline
\end{tabular}

Results of meta-analysis

\section{Effect of DEX on incidence of nausea}

Fourteen studies (three of them ${ }^{[15,16,17]}$ had subgroups of different dosage of dexmedetomidine, thus can be taken as two observation groups for analysis) reported the incidence of nausea, involving 614 subjects in the observation group(DEX) and 610 in the control group(saline). According to the heterogeneity test $\left(\mathrm{I}^{2}=23 \%\right)$, fixed-effects model was selected to conduct the meta-analysis and results were shown in figure 2.Metaanalysis results suggested that the incidence of adverse reactions of nausea in the DEX group was lower than that in the control group, and the difference was statistically significant $[\mathrm{OR}=0.12,95 \% \mathrm{Cl}(0.09,0.17), \mathrm{P}$ $<0.00001]$.

Figure 2. Effect of DEX on incidence of nausea 
The incidence of vomiting was reported in fourteen studies (three of them ${ }^{[15,16,17]}$ had subgroups),including 614 cases in the observation group and 610 cases in the control group. The heterogeneity test showed that $\mathrm{I}^{2}$ $=29 \%$, thus the fixed-effects model was used. Meta-analysis results showed that the incidence of adverse reactions to vomiting in the observation group was lower than that in the control group, and the difference was statistically significant $[\mathrm{OR}=0.12,95 \% \mathrm{Cl}(0.09,0.18), \mathrm{P}<0.00001]$.

Figure 3. Effect of DEX on incidence of vomiting

Effect of DEX on incidence of facial flushing

Fourteen studies (three of them ${ }^{[15,16,17]}$ had subgroups), with 609 cases in observation group and 605 cases in control group, reported the incidence of facial flushing. Heterogeneity test showed that $\mathrm{I}^{2}=32 \%$ and fixed effect model was selected for analysis. Results were shown in figure 4,which indicated that the incidence of facial flushing adverse reactions in the observation group was lower than that in the control group with statistically significance $[\mathrm{OR}=0.21,95 \% \mathrm{Cl}(0.16,0.29), \mathrm{P}<0.00001]$.

Figure 4. Effect of DEX on incidence of facial flushing

Effect of DEX on incidence of chest distress

Fourteen studies (three of them ${ }^{[15,16,17]}$ had subgroups), 609 cases in the observation group and 605 cases in the control group, reported the incidence of chest distress. Heterogeneity was detected and $\mathrm{I}^{2}=52 \%$, thus random-effects model was selected for analysis. Results was shown in figure 5,which suggested that the incidence of adverse reactions to chest distress in the observation group was lower than that in the control group, and the difference was statistically significant [OR $=0.19,95 \% \mathrm{Cl}(0.12,0.30), \mathrm{P}<0.00001]$.

Figure 5. Effect of DEX on incidence of chest distress

Effect of DEX on incidence of hypertension

The incidence of hypertension was reported in nine of the included trials(one of them ${ }^{[16]}$ included subgroups),318 cases in the observation group and 314 cases in the control group. Heterogeneity test showed $\mathrm{I}^{2}=36 \%$ and fixed-effects model was selected. Results of meta-analysis were shown in figure 6 . It indicated that the incidence of adverse reactions of hypertension in the observation group was lower than that in the control group significantly [OR $=0.09,95 \% \mathrm{Cl}(0.05,0.14), \mathrm{P}<0.00001]$.

Figure 6. Effect of DEX on incidence of hypertension

Effect of DEX on incidence of tachycardia

The incidence of tachycardia was reported in nine studies with 303 cases in the observation group and 299 cases in the control group. According to heterogeneity test, $\mathrm{I}^{2}=30 \%$, thus fixed-effects model was applied. Results was shown in figure 7, which showed that the incidence of adverse reactions to tachycardia in the 
observation group was significantly lower than that in the control group [OR $=0.04,95 \% \mathrm{Cl}(0.02,0.07), \mathrm{P}<$ 0.00001].

Figure 7. Effect of DEX on incidence of tachycardia

\section{Discussion}

Uterotonic agents such as oxytocin, carboprost tromethamine, carbetocin were commonly used drug in cesarean section for the prevention of postpartum hemorrhage. But except of uterine smooth muscle, these agents usually have effects on gastrointestinal tract, bronchus and vascular smooth muscle, due to the lack of smooth muscle selectivity, leading to nausea, vomiting, increased heart rate and other adverse reactions ${ }^{[23]}$.These side effects not only bring discomfort to the mothers, but also greatly increase the risk of perioperative surgery.

Dexmedetomidine, as a new selective alpha-2 adrenergic agonist, has a high selectivity to alpha-2 adrenergic receptor and has analgesic, sedative and anti-anxiety effects. It can block sympathetic during perioperative period, stabilize the cardiovascular system and reduce the need for anesthetics without affecting respiration ${ }^{[24]}$. The pharmacological mechanism of dexmedetomidine is multifaceted and complicated. On one hand, it acts on alpha-2 adrenalin receptors in presynaptic membrane and postsynaptic membrane of the spinal cord, inhibiting the release of adrenalin and breaking up the transmission of pain signals ${ }^{[25]}$. On the other hand, by activating postsynaptic membrane receptors, the concentration of catecholamines in blood can be reduced to alleviate the abnormal increase of blood pressure and heart rate caused by stress response ${ }^{[26]}$. Dexmedetomidine can also relieve spasm of gastrointestinal smooth muscle and blood vessels, and reduce the incidence of nausea, vomiting, chest and abdominal pain, facial flushing and other adverse reactions by anti-sympathetic effect and diastole of pulmonary and peripheral small blood vessels ${ }^{[27]}$.In addition, studies have shown that dexmedetomidine may reduce nausea and vomiting by directly acting on the locus coeruleus and inhibiting the vomiting center in the central nervous system that controls the downstream region of the medulla oblongae ${ }^{[28]}$.

Dexmedetomidine has variable pharmacological effects, but does it have an effect on adverse reactions caused by uterotonics, such as nausea, vomiting, facial flushing, chest distress, hypertension and tachycardias? To make a clear of it, we carry out a meta-analysis in this study. Our study evaluated the preventive effects of dexmedetomidine on the side effects of uterotonics in cesarean section surgery. Eventually we included fifteen studies with a total of 1174 patients. According to the results of meta-analysis, incidence of adverse reactions such as nausea, vomiting, facial flushing, chest distress, hypertension and tachycardia in DEX group were all lower than that in the control group, and the difference is remarkablely significant $(P<0.01)$, suggesting that dexmedetomidine can actually prevent and reduce the incidence of adverse reactions of uterotonics including nausea, vomiting, facial blushing, chest distress, hypertension and tachycardia during caesarean process.

Finally, our study has some limitations. Although all the literatures included in this study were RCTs, the number of articles and the sample size were still small. As for that most of the studies were from China and the quality of some literatures was not so high, there was inevitably the possibility of bias in the results. Most 
of the included literature did not report the total incidence of adverse reactions, so we did not conduct a bias analysis of the total incidence of adverse reactions in this study. In addition, there were differences in the dosage of dexmedetomidine and the way of administration of uterotonics in the included studies, which were not further evaluated in this paper due to the complicated classifications.

\section{Conclusions}

In a word, we believe that in order to obtain reliable evidence of higher quality and provide more references for clinical medication, more high-quality, multi-center and large-sample of RCTs should be carried out in the future. In conclusion, the current meta-analysis suggests that dexmedetomidine is effective for the prevention of side-effects caused by uterotonics in caesarean section.

\section{Abbreviations}

DEX: dexmedetomidine; RCTs: randomized controlled trials; PRISMA: Preferred Reporting Items for Systematic Reviews and Meta-Analyses ;CNKI: Chinese National Knowledge Infrastructure; OR: odds risks; $\mathrm{Cl}$ : confidence interval.

\section{Declarations}

Ethics approval and consent to participate

Not applicable.

Consent to publish

The authors all agree to the publication of the article.

Availability of data and materials

All data generated or analyzed during this study are included in this published article.

Competing interests

The authors declare no conflict of interest.

Funding

This research received no specific grant from any funding agency in the public or commercial.

Authors' Contributions

YY and YR conceived and designed the study.LK and HW were in charge of data processing. LK and XS wrote the paper. FQ reviewed and edited the manuscript. All authors read and approved the manuscript.

Acknowledgements

Page 10/15 
The authors are grateful to the members of department of VIP anesthesiology department of Jinshan hospital for their extensive support throughout the study.

\section{References}

[1]Obstetrics section, obstetrics and gynecology branch, Chinese medical association. Guidelines for the prevention and management of postpartum hemorrhage (draft) [J]. Chinese J Obstet Gynecol, 2009, 49(7):554-557.

[2]World Health Organization[WHO]. Department of Reproductive Health and Research. WHO recommendations for the prevention and treatment of postpartum haemorrhage.[J]. Geneva Switzerland Who, 2012, 22(6):1025-1041.

[3]Gizzo S, Patrelli T, Gangi S, et al. Which Uterotonic Is Better to Prevent the Postpartum Hemorrhage? Latest News in Terms of Clinical Efficacy, Side Effects, and Contraindications: A Systematic Review[J]. Reproductive Sciences, 2013, 20(9):1011-1019.

[4]Mo Y, Qiu S. Effects of dexmedetomidine in reducing post-cesarean adverse reactions[J]. Experimental \& Therapeutic Medicine, 2017, 14(3):2036-2039.

[5]Bao Z, Zhou C, Wang X, et al. Intravenous dexmedetomidine during spinal anaesthesia for caesarean section: A meta-analysis of randomized trials[J]. Journal of International Medical Research, 2017: 45(3):924932.

[6]Miao S, Shi M, Zou L, et al. Effect of intrathecal dexmedetomidine on preventing shivering in cesarean section after spinal anesthesia: a meta-analysis and trial sequential analysis[J]. Drug Design Development and Therapy, 2018,12:3775-3783.

[7]Zhang J, Zhang $X$, Wang $H$, et al. Dexmedetomidine as a neuraxial adjuvant for prevention of perioperative shivering: Meta-analysis of randomized controlled trials[J]. Plos One, 2017, 12(8):e0183154.

[8]Chen Y. Effect observations of dexmedetomidine on preventing adverse reactions caused by carboprost in cesarean section[J].Journal of Clinical Research,2015,32(12):2347-2348,2352.

[9]Li Q, Wang W, Yang C, et al. Observation on the effect of dexmedetomidine on reduction of adverse reactions induced by carboprost tromethamine during cesarean section [J].Maternal \& Child Health Care of China,2015, 30(35):6368-6370.

[10]Sun W, Zhou L, Wang J, et al. Comparison of dexmedetomidine and propofol in the prevention of adverse reaction in cesarean section caused by car-boprost tromethamine[J]. Chinese General Practice,2014(30): 3617-3619.

[11] Li H, Wang Y, Liu H. The effects of dexmedetomidine and propofol in prevention adverse reaction of carboprost tromethamine in the cesarean section surgery[J].Journal of Clinical and Experimental Medicine, 2015(13):1130-1133. 
[12]Duan L, Jing Gui.Effects of dexmedetomidine combined with droperidol in preventing adverse reaction in cesarean section caused by carbetocin [J]. Chinese Journal of Woman and Child Health Research,2018,29(10):42-46.

[13]Liang $Y$, Yang $X$, Wang $X$, et al. Comparison of efficacy of midazolam combined with fenflurant mixture and dexmedetomidine in preventing adverse reactions of carprost tromethamine during cesarean section [J].Journal of Clinical Medical Literature,2017(63):12424-12425.

[14]WU L, WANG Q.Comparative research of dexmedetomidine and midazolam in prevention of carboprostinduced adverse;reactions in cesarean section[J].China Practical Medical,2016(2):3-5.

[15]Li M.Comparation of preventive effects of different concentrations of dexmedetomidine on adverse reactions caused by Carboprost Tromethamine in cesarean section[J].Journal of Clinical Medical Literature,2016(55):11012.

[16] Wang L, Liao M, LaiY, et al. Effect of different concentrations of dexmedetomidine on adverse effects induced by carboprost tromethamine during cesarean delivery[J].Modern Hospital,2015(7):18-20.

[17] Liu Y, Chen H X, Kang D L, et al. Influence of dexmedetomidine on incidence of adverse reactions introduced by hemabate in postpartum hemorrhage during cesarean section.[J]. International Journal of Clinical \& Experimental Medicine, 2015, 8(8):13776.

[18]Ni Y, Gui B, Jiang X, Ding Zn, et al.Efficacy of small dose of dexmedetomidine for prevention of adverse effects induced by carboprost in patients undergoing caesarean section[J].Chinese Journal of Anesthesiology,2014, 34(7):830-832.

[19]Lv X, Hao J.Effect of dexmedetomidine for prevention of uterotonic adverse reaction in cesarean section [J]. Journal of Xinxiang Medical University,2015,32(11):1022-1024.

[20]Yang M, Zhang Q, Tao X. Effects of dexmedetomidine on adverse reactions during cesarean section induced by carprost[J].Jiangxi Medical Journal,2016, 51(3):271-273.

[21]Xing Y. The role of dexmedetomidine in preventing adverse reactions and shivering during cesarean section [J],Medical Information,2016,29(22):96-97.

[22]Yuan M,Chen Y. Efficacy of dexmedetomidine in preventing adverse reactions of hemabate during cesarean section[J]. Jiangsu Medical Journal,2015,(21):2597-2598.

[23]Bai J,Sun Q,Zhai H. A comparison of oxytocin and carboprost tromethamine in the prevention of postpartum hemorrhage in high-risk patients undergoing cesarean delivery[J]. Experimental and Therapeutic Medicine,2014,7(1): 46- 50.

[24]Kemp KM, Henderlight L, Neville M. Precedex: Is it the future of cooperative sedation? [J]. Nursing,2008,38 Suppl: 7-8. 
[25]Baljit SB, Satpal. Role of dexmedetomidine in anesthesia and critical care[J].Journal of Evolution of Medical and Dental Sciences, 2014,3(43): 10711-10721.

[26] Naaz S,Ozair E. Dexmedetomidine in Current Anaesthesia Practice-A Review[J]. Journal of Clinical \& Diagnostic Research, 2014, 8(10):1-4.

[27]Seyrek, M,Halici, Z,Yildiz, O,et al. Interaction between dexmedetomidine and alpha-adrenergic receptors: emphasis on vascular actions[J]. Journal of Cardiothoracic and Vascular Anesthesia, 2011,25( 5):856-862.

[28]Bajwa SJ,Gupta S,Kaur J,et al. Reduction in the incidence of shivering with perioperative dexmedetominine『a randomized prospective Study[J].Anaesthesiol Clin Phamacol,2012,28(1):86-91】

\section{Figures}



\section{Figure 1}

Flow diagram of the study selection process

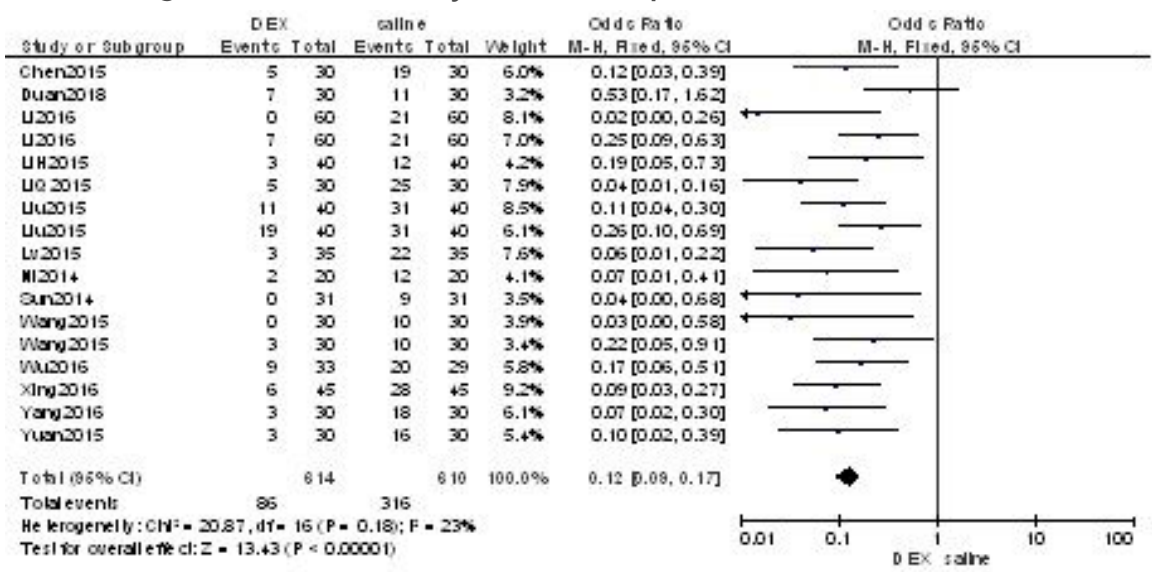

\section{Figure 2}


Effect of DEX on incidence of nausea

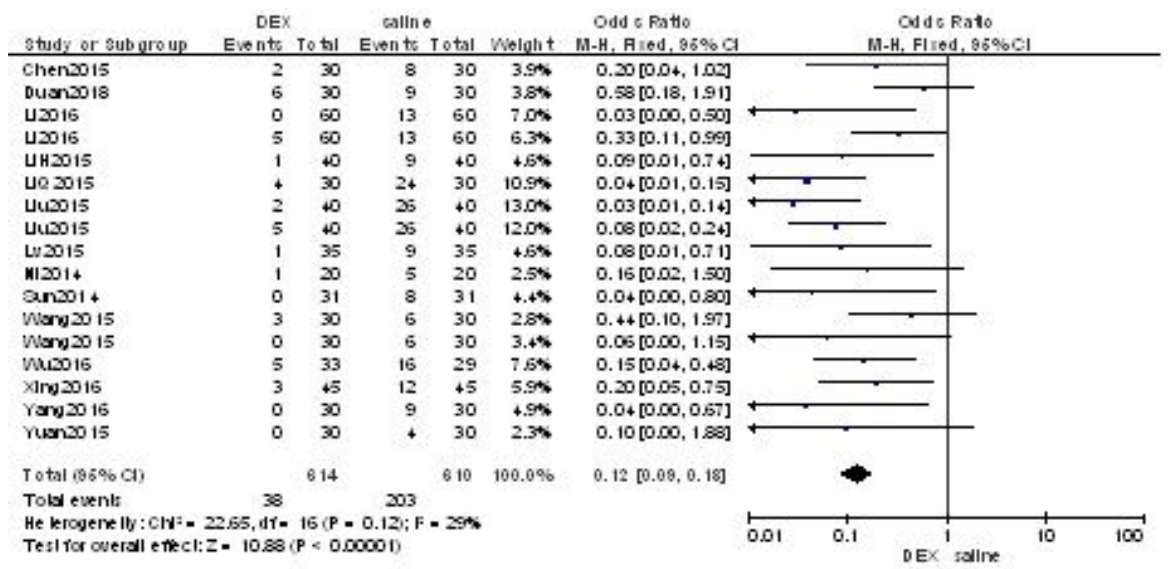

\section{Figure 3}

Effect of DEX on incidence of vomiting

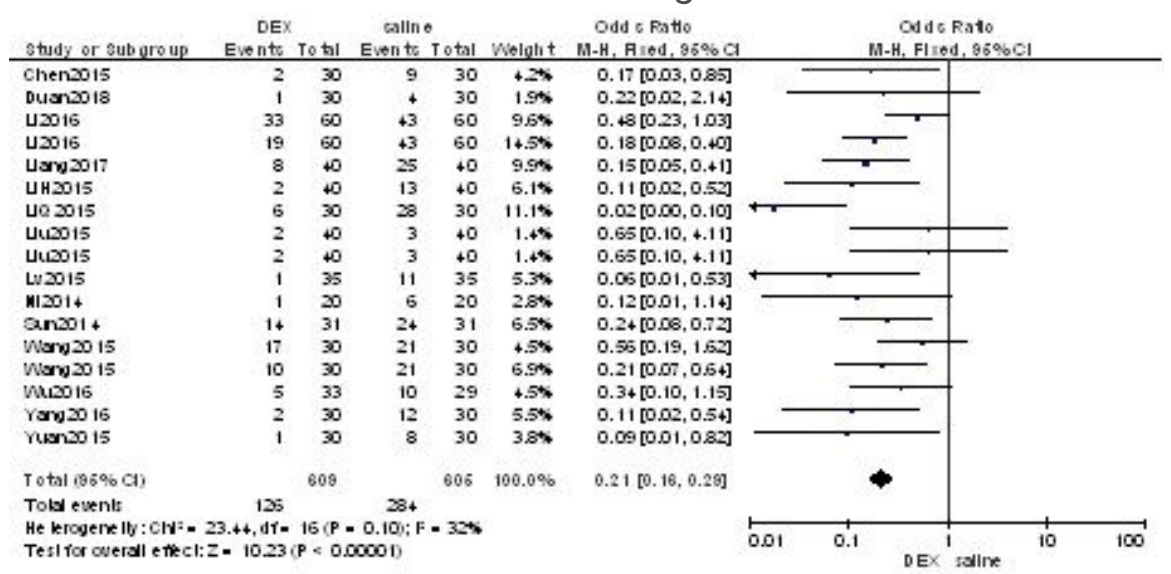

\section{Figure 4}

Effect of DEX on incidence of facial flushing

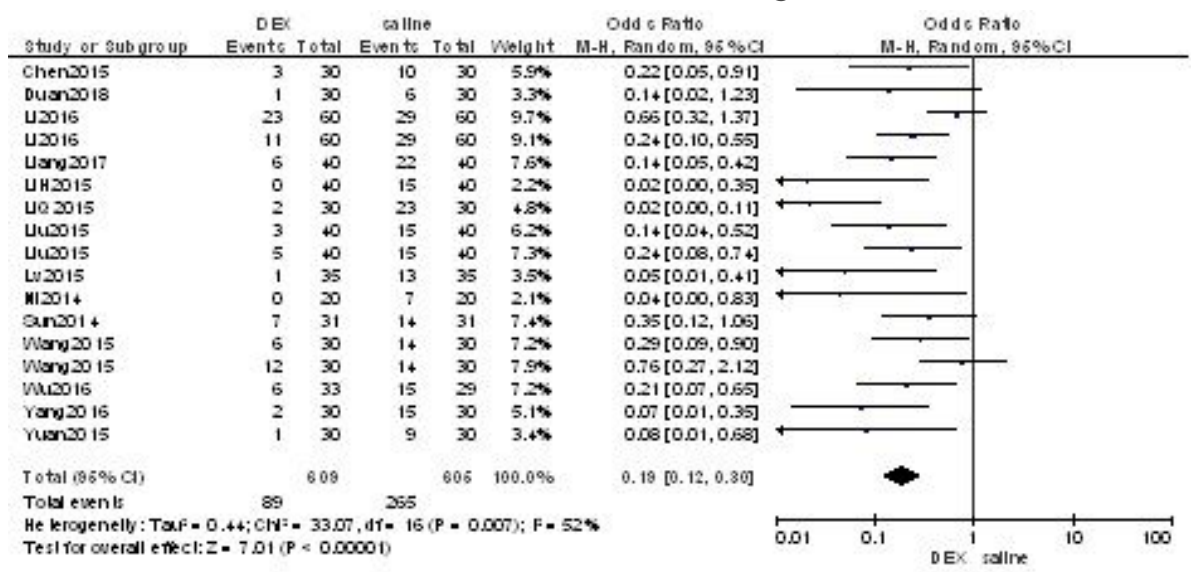

\section{Figure 5}






\section{Figure 6}

Effect of DEX on incidence of hypertension

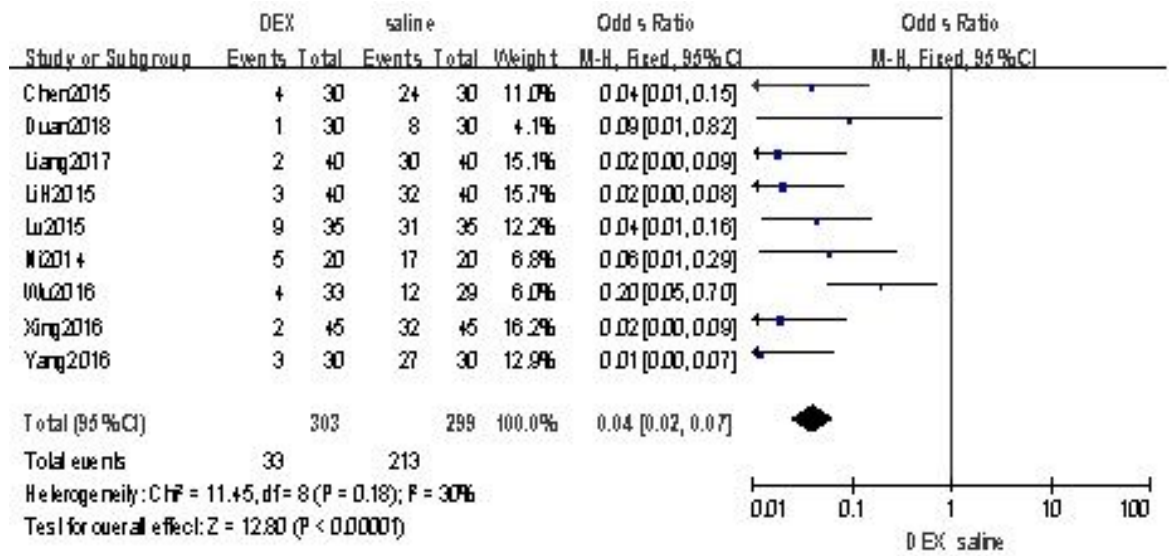

Figure 7

Effect of DEX on incidence of tachycardia

\section{Supplementary Files}

This is a list of supplementary files associated with this preprint. Click to download.

- PRISMA2009checklist.doc 